\section{Medieval Novgorod: epitome of early urban life in northern Europe}

Novgorod is a waterlogged site that has preserved a uniquely detailed record of medieval life, where even personal lettters written on birch bark have survived buried in the soil. Now British and Russian archaeologists are recovering new evidence dence of how the people lived and of the houses they built,as three members of staff of the Institute report.

\section{Too much of a good thing? Pottery and other finds from medieval Novgorod Clive Orton}

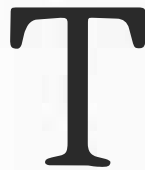
he small Russian town of Novgorod (literally "new town"; Fig. 1) is situated on the River Volkhov between Moscow and St Petersburg. It has been a source of inspiration to medieval urban archaeologists across Europe since largescale excavations started there in the 1950s. They have continued ever since and Novgorod's influence can be seen, for example, in the classic series of excavations carried out by the British archaeologist Martin Biddle at Winchester in the 1960s. Archaeological investigations a re now carried out under the auspices of the Novgorod Archaeological Expedition of Moscow University and the Institute of Archaeology of the Russian Academy of Sciences; and recently the Russian archaeologists have been joined by British colleagues from Bournemouth University and the UCL Institute of Archaeology.

\section{Finds from medieval Novgorod} amazing degree of preservation at the site, as well as the extent and duration of the typically found in excavations of other and bone are excellently preserved, as are
What makes the archaeology of the medieval city of Novgorod so special is the excavations. The medieval strata, which lie above a natural grey clay, consist of a peat-like deposit, known as the "cultural layer", which has accumulated at a rate of about $1 \mathrm{~m}$ per century from the tenth to the fifteenth century AD. The condition of these deposits, which are both waterlogged and anaerobic, has preserved a wider range of artefacts and organic materials than is medieval European cities. Wood, leather metals and other inorganic materials. Less striking, but equally important in our attempts to reconstruct medieval life at Novgorod, are "ecofacts" such as animal dung, plant remains, bones of small mammals, birds and fish, and even fish scales and pine needles.

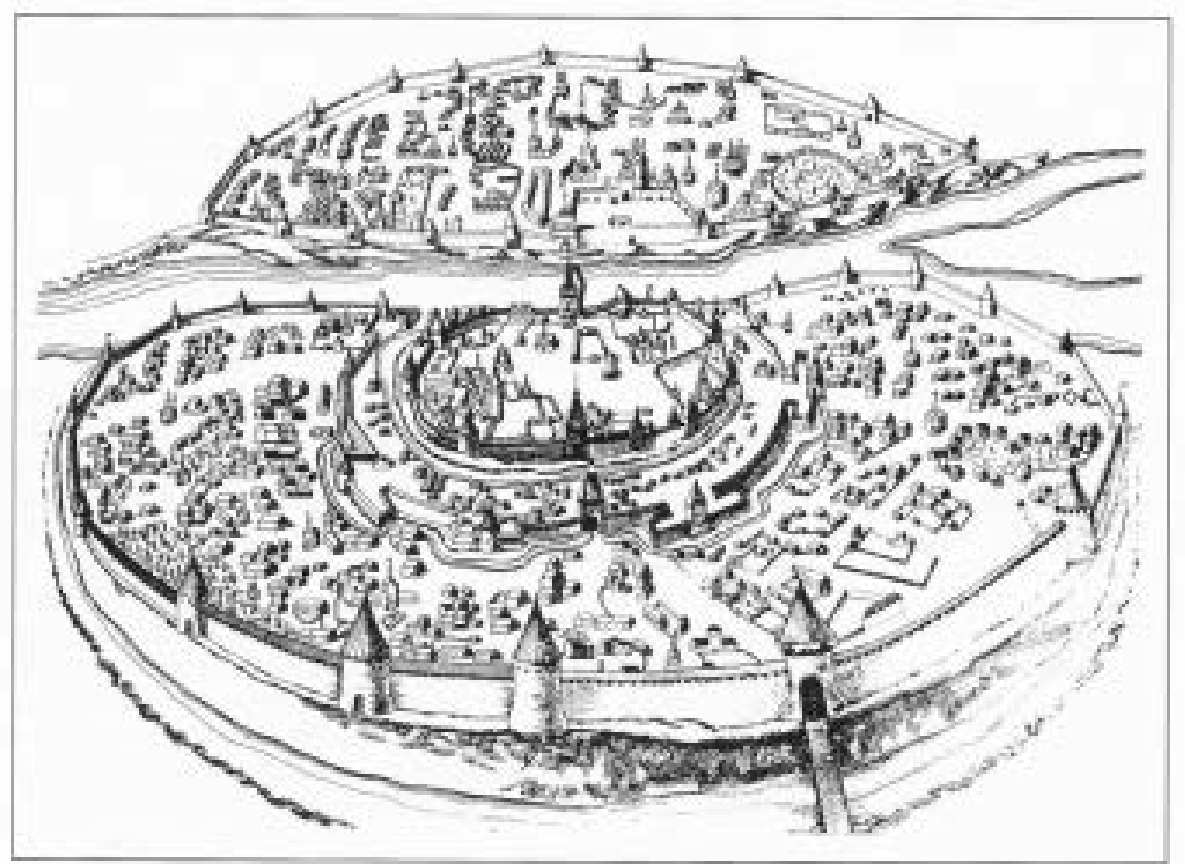

Whole classes of artefacts, scarcely known in archaeological deposits elsewhere, have been found in great numbers and have been extensively studied. Pride of place in Russian eyes goes to the documents inscribed on pieces of birch bark which can still be read today and of which over 900 have so far been found. They are mostly informal little letters written by ordinary townspeople to each other, about everyday matters - buying and selling, family relations, and even hooliganism. Some were clearly written by women and some showed that children started to learn to write as early as the age of six. Funds are being sought to publish the whole corpus in modern Russian and English. Equally impressive are the remains of several types of musical instrument, which have been reconstructed and studied at the Novgorod Centre for Musical Antiquities. Such finds give unique insights into medieval life.

The Bournemouth/UCL project We therefore felt greatly privileged to be invited to take part in a project to collaborate with the Novgorod Archaeological Expedition. ${ }^{1}$ Funded by the International Association for the Promotion of Cooperation with Scientists from the New Independent States of the former Soviet Union, Bournemouth University has been involved in this project for several years, ${ }^{2}$ concentrating initially on the study of animal bones and plant remains. The second stage of the project started in 1998 and involves staff and students from the Institute of Archaeology, as well as David Gaimster of the British Museum. It is concentrating on pottery, particularly the local coarse pottery (Clive Orton); and imports from western Europe and the Baltic region (David Gaimster); on wooden artefacts, technology and wooded environments (Jon Hather); and on excavation methods and recording techniques (Andrew Reynolds). When we became involved, a system of excavation, recording, and the preservation and study of finds over many years, was already in operation. Although well preserved in the soil, organic artefacts can deteriorate rapidly once removed from their protective environment, and must be quickly transferred to the safety of the laboratory. Much effort has gone into developing procedures for recording accurately and preserving speedily what in Britain we call "small finds" - objects of individual archaeological importance in their own right. Keeping up with the steady flow of such objects occupies most of the energies of the hard-pressed excavation staff, who therefore have relatively little time to spare for the more mundane "bulk" finds, which are potentially more of statistical than individual value. As always in archaeology, priorities are at work here, and they have led inevitably to a bias towards the more striking and unusual classes of artefact.

Figure 1 Medieval Novgorod c. AD 1700 (from the frontispiecein Brisbane(ed.)(see n. 2). 


\section{Studying the local pottery}

The aim of part of the project is to help redress this bias by developing ways in which the bulk finds, and in particular the locally made coarse pottery, can be recorded and analyzed in a way that is not too time consuming, but which nevertheless has the potential for answering questions about the pottery industry itself, about wider pottery distribution and trade, and about the value of the pottery as evidence for dating. Although chronological dating at Novgorod rests mainly on the many tree-ring dates that are available from timber buildings and roadways, there is much interest in using pottery to extrapolate these dates to other sites in the region, where organic preservation may be less good and the more durable pottery may be the only surviving evidence with potential for dating.

Our first impression was of the sheer quantity of pottery. For example, trench $\mathrm{x}$ of the Troitsky site $\left(775 \mathrm{~m}^{2}\right)$, in the southwestern part of the town south of the kremlin (Fig. 2), yielded about 250,000 sherds of pottery, whereas the first three years' excavation of the Troitsky trench XI $\left(320 \mathrm{~m}^{2}\right)$ yielded about half that amount. ${ }^{3}$ Although only rim and base sherds had been retained (the rest had been counted before being discarded), the pottery from trench XI alone occupied much storage space, and we began to understand the past reluctance of excavators to retain more than the "special" pottery (e.g. imports, whole vessels and makers' marks).

I do not wish to give the impression that little work had previously been done on the coarse pottery. Working in the 1950s on material from the other very large excavation in the town, the Nerevsky site north of the kremlin (Fig. 2), G. P. Smirnova had devised a typology of the coarse pottery and had related it to the tree-ring dates of the timber structures on that site. Work that was unfinished at her death in the 1970s is being prepared for publication, and there has been a continued interest in the earliest (handmade) pottery currently being studied by Peter Malygin of the University of Tver. However, many questions about the production, distribution and use of the pottery remained unanswered. For example, we did not know whether the pottery was made inside or outside the city, or indeed imported from another centre (although that seemed unlikely), and whether the city was supplied from a single source or from many. Nor did we know whether and how the modes of production and distribution changed from the tenth to the fifteenth century.

Much of the first season was spent in cataloguing in detail a sample of the twelfthfifteenth century local coarse pottery from Troitsky XI, using methods developed at the Museum of London for dealing with large urban ceramic assemblages. Statistical analysis of this catalogue is now beginning, using computer software previously

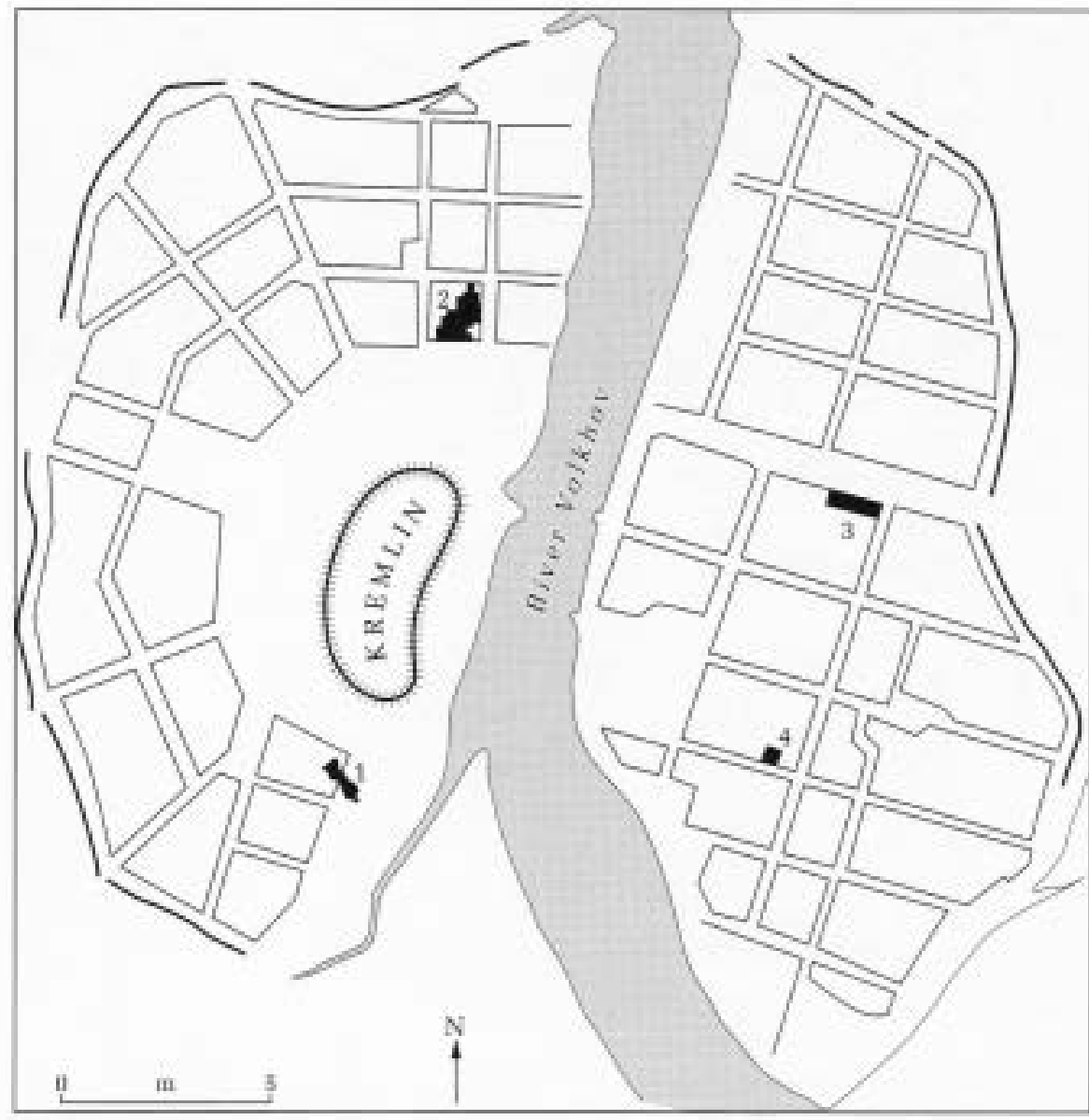

Figure 2 Plan of Novgorod, showing the locations of the excavations mentioned in the text:Troitsky (1) Nerevsky (2) Fyodorovsky (3) Duboshin (4) (based on Fig. 1.1 in Brisbane (ed.) (see n. 2).

developed at the Institute of Archaeology. In parallel with this work, Peter Malygin is studying the tenth- to eleventh-century handmade pottery, Oleysia Rud of Novgorod's Museum of History, Architecture and Art is studying the decorative motifs used on the pottery, and petrographic analysis is being carried out at the University of Lund, Sweden.

Clues to the production of pottery appeared as soon as we started to catalogue the coarse pottery. A small proportion of the pottery (usually about 1 per cent, but rising to 10 per cent in some fourteenthcentury deposits) was recognized as consisting of "wasters", that is, damaged and rejected pottery from the manufacturing process itself (Fig. 3). The damage took the form of severe cracking and in some cases a "frothy" appearance to the fabric of the vessel. Such damage can occur through firing to too high a temperature, or through an over-rapid rise in temperature while firing, but not, as far as we know, through events such as intense burning after the pottery has been fired. At the same time, examination by David Gaimster of the pottery (mostly imports) retained from the Duboshin site on the eastern side of the river (Fig. 2), which was excavated from 1977 to 1981, unexpectedly revealed a group of lead-glazed redware wasters.
They were found in deposits that also produced a group of imported lead-glazed redware jugs, which originated in either the Low Countries or the southern Baltic region in the period c. AD 1250-1350. Because glazed pottery is very rare in Novgorod at this period, these wasters and a smaller similar group from Troitsky viII probably represent a failed attempt by local potters to emulate the imported redwares.

\section{The imported pottery ${ }^{4}$}

The imported pottery retained in the Novgorod Museum can be divided into two very broad groups, that coming from the south and that coming from the west. The former includes highly decorated Islamic pottery, amphoras thought to be from the Black Sea region, and coarser glazed wares possibly from the Kiev area, all of which have been studied locally. The second group has received less attention, and its study was one of the aims of our project. There are two distinct phases of Western imports. The first comprises decorated glazed redware jugs of the late thirteenth and early fourteenth centuries, which, as mentioned above, come from either the Low Countries or the Baltic region (further work will be undertaken to attempt to resolve this question), and also a few examples of similar wares from Rouen (northern 


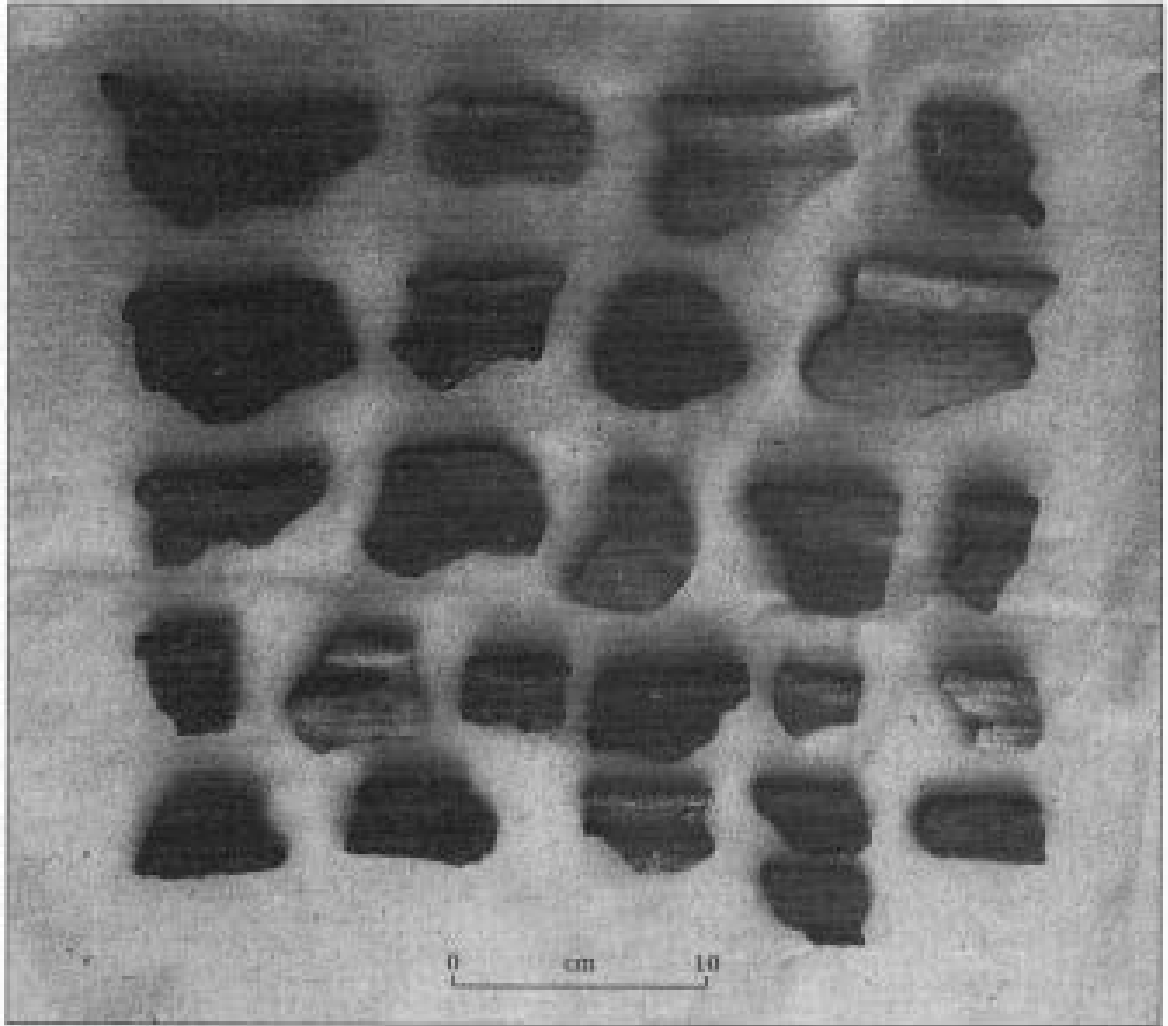

Figure 3 Examples of pottery "wasters" from the Troitsky XI excavation

France) and Grimston (Norfolk). The second phase comprises stonewares from various parts of Germany, dating from the mid-fourteenth century to the sixteenth century. Their occurrence varies across the city, with the greatest concentration so far observed being in the quarter occupied by merchants from the island of Gotland in the Baltic. Overall, the proportions of imports are low in comparison to other sites around the Baltic.

\section{Summary of the local and imported pottery}

It is clear that the bulk of the ceramic needs of the city were provided by the local unglazed coarsewares, mostly apparently cooking pots but also some smaller jars and bowls. One must be careful in assigning function to vessels on the basis of their shape; one "cooking pot" shape was decorated with strips of birch bark (Fig. 4), which would not have withstood any kind of heating. However, many vessels of this shape do show evidence of heating, and some even retain residues of their former contents.

Imports seem to have arrived either as containers (the amphoras) or as decorative or high-quality tableware. The local pottery tradition shows clear continuity in function and general technique, combined with a pattern of changing detail of shape and decoration, which will be explored in later stages of the project.

\section{It can't all have been pottery}

It is very easy for a pottery specialist to ignore the influence and effect of other materials, whether as competition or inspiration for the potters. This is especially true if those other materials have not survived, as is often the case in British archaeological sites. Novgorod serves as a wonderful corrective to this attitude. For example (and as Jon Hather's article on pp. 37-38 shows), it would be quite impossible to ignore the finds of wooden artefacts. A superb twelfth-century wooden bowl, found in 1998 on Troitsky XII, shows the quality of competing materials (Fig. $5 a, b)$, and at a more mundane level a large tenth-century wooden mallet found by our students in Troitsky XI illustrates the diversity of everyday domestic objects. It is salutary to remember that almost every object in pottery could have been made in other materials.

\section{Notes}

1. I and my co-authors of the articles on Novgorod in this issue of $A I$, Andrew Reynolds and Jon Hather, are greatly indebted to our Russian colleagues for inviting us to collaborate with them in the investigation. We are grateful, too, to our colleagues from Bournemouth University who initiated the international project.

2. See The archaeology of Novgorod, Russia: recent results from the town and its hinterland, M. A. Brisbane (ed.) (Lincoln: Society for Medieval Archaeology Monograph Series no. 13, 1992). This book provides a good overview in English and an introduction to the copious Russian

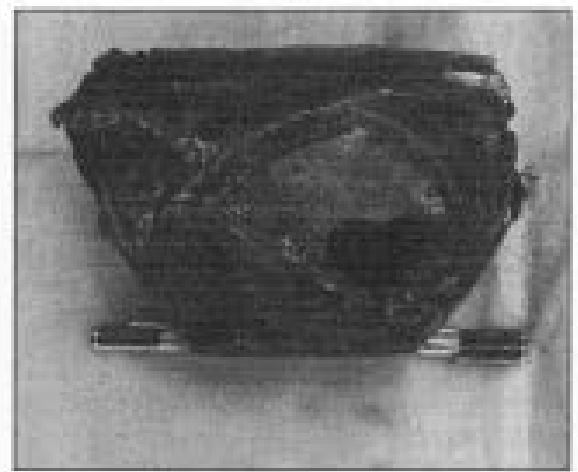

Figure 4 Coarseware pottery vessel with birch-bark binding, dated c. $A D$ 1300, from the Fyodorovsky VI excavation (Fig. 2).
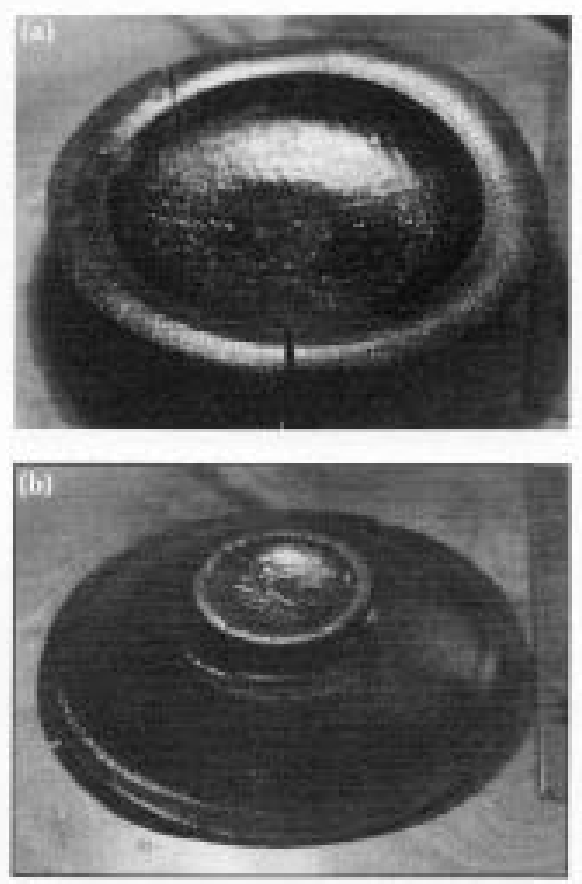

Figure 5 A twelfth-century lathe-turned ashwood bowl from the Troitsky XII excavation, (a) from above, (b) the underside.

literature on Novgorod.

3. Dr Peter Gaidukov of the Novgorod

Archaeological Expedition provided valuable information about the quantities of pottery excavated at the Troitsky site.

4. Dr David Gaimster of the British Museum, who is my colleague in the ceramic aspects of the project, provided information on the imported pottery, particularly the stonewares. 
Excavations at medieval Novgorod, 1998

\section{Andrew Reynolds}

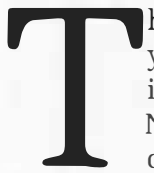

he combined results of many years of large-scale archaeological excavations at medieval Novgorod have allowed Russian colleagues to investigate the cultural record to a degree almost unparalleled in any other European town. Prior to the excavations undertaken by the UCL Institute of Archaeology in July 1998, research had been directed mainly towards a typological understanding of the archaeological remains, particularly the evolution of building types, but also the typological changes observable in the extraordinary range of domestic and personal objects found during excavations (see Clive Orton's article on pp. 31-33). Novgorod therefore constitutes an important point of reference for those working on artefacts from other, geographically distant, settlements of the medieval period.

Urban excavations in western Europe, particularly Britain, have been carried out on a much smaller scale than in Novgorod and this has resulted in different sets of questions beingasked by thearchaeologists involved. In Britain, urban archaeologists have explored changes in the function of particular excavated areas by applying modern statistical approaches to the range of artefactual and ecofactual materials recovered. As a result, they have, as far as the archaeology allows, gained a refined understanding of the economic bases of medieval towns. However, this achievement contrasts with the advanced understanding of early townscapes achieved by Russian archaeologists over the past 50 years or so.

With these contrasts in mind, the UCL excavations were designed to answer very specific questions based on a British-style approach to the excavation and, more importantly, to the recording of archaeological deposits. When an excavation is conducted, choices must be made about what is thought to be important and what is not. Frequently, the importance of a sequence of archaeological deposits will not be apparent until the excavations are completed and the various specialists have compared the results of their findings. This realization, together with the need to record complex sequences of past occupation in Britain's post-war redeveloping city centres, led archaeologists working in London to design a system of archaeological recording that would allow a comprehensive written and drawn record to be made of every single episode of deposition or change within individual excavations.
Therefore, at Novgorod, instead of excavating by the Russian system of arbitrary levels, or spits, of $20 \mathrm{~cm}$ depth, each layer or structural feature was described, drawn and photographed prior to its removal - a process that greatly facilitated, for example, Jon Hather's investigations of wood use (described in his article on pp. 37-38). This method of excavation is called single context recording; its principal benefit is that the archaeological sequence can be reconstructed after its destruction by excavation.

The 1998 excavations aimed to explore in intimate detail the techniques and materials employed in the construction of individual buildings. Indeed, one of the most fundamental questions to be addressed by the UCL team was how and where the houses and other structures found in medieval Novgorod were built. Were the buildings assembled elsewhere by carpenters and reassembled within the town, or were the basic techniques of carpentry practised in individual households? We also wished to explore evidence for the changing functions of individual buildings by looking in detail at the deposits that they contained rather than just the associated artefacts, of which very few could definitely be related to actual occupation.

\section{Excavating for answers}

Excavations were carried out in two areas, one each in trenches XI and XII of the Troit-

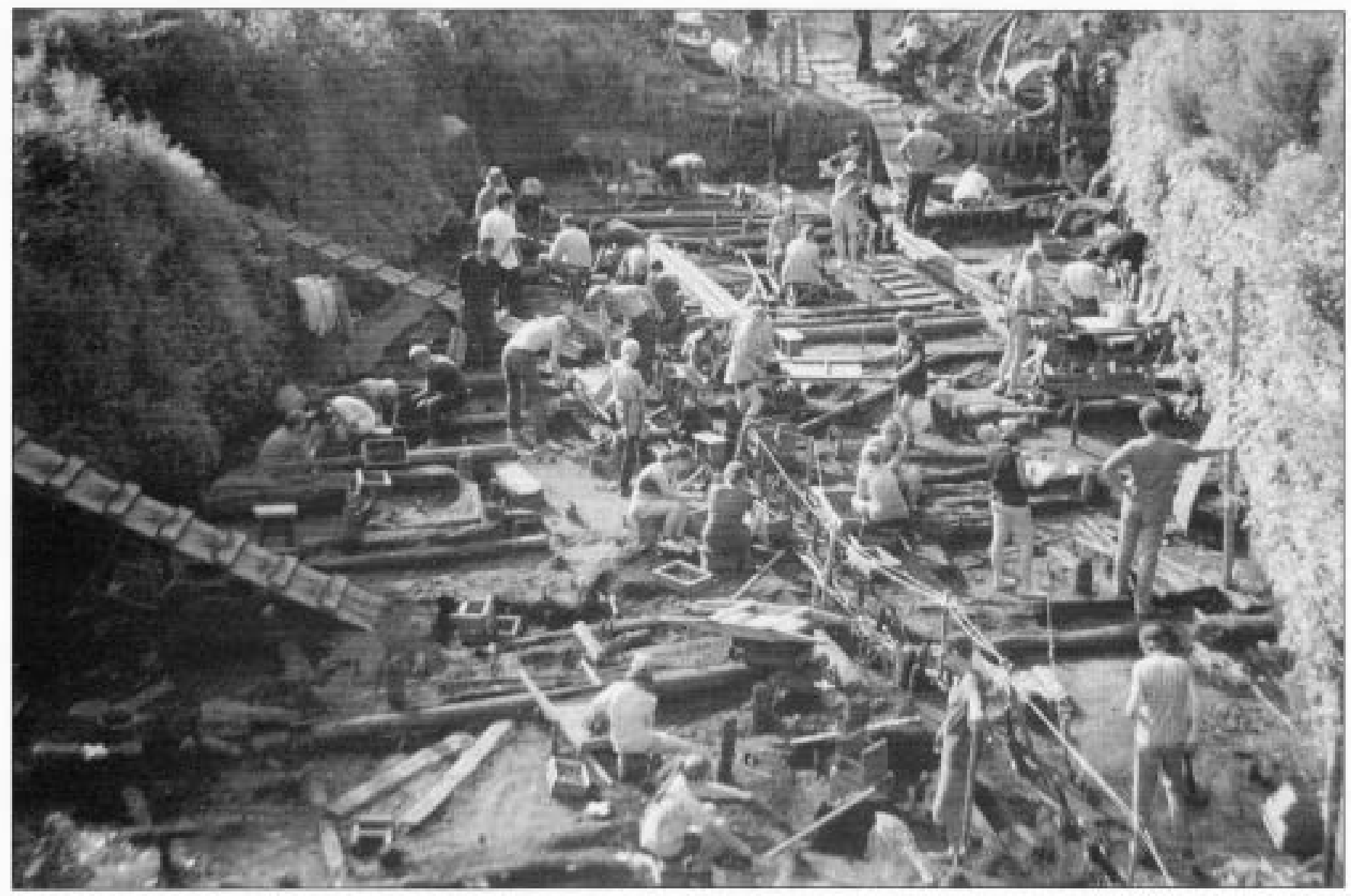

Figure 1 Excavation of late tenth-century houses under way at the Troitsky XI site, 1998; view from the east. 


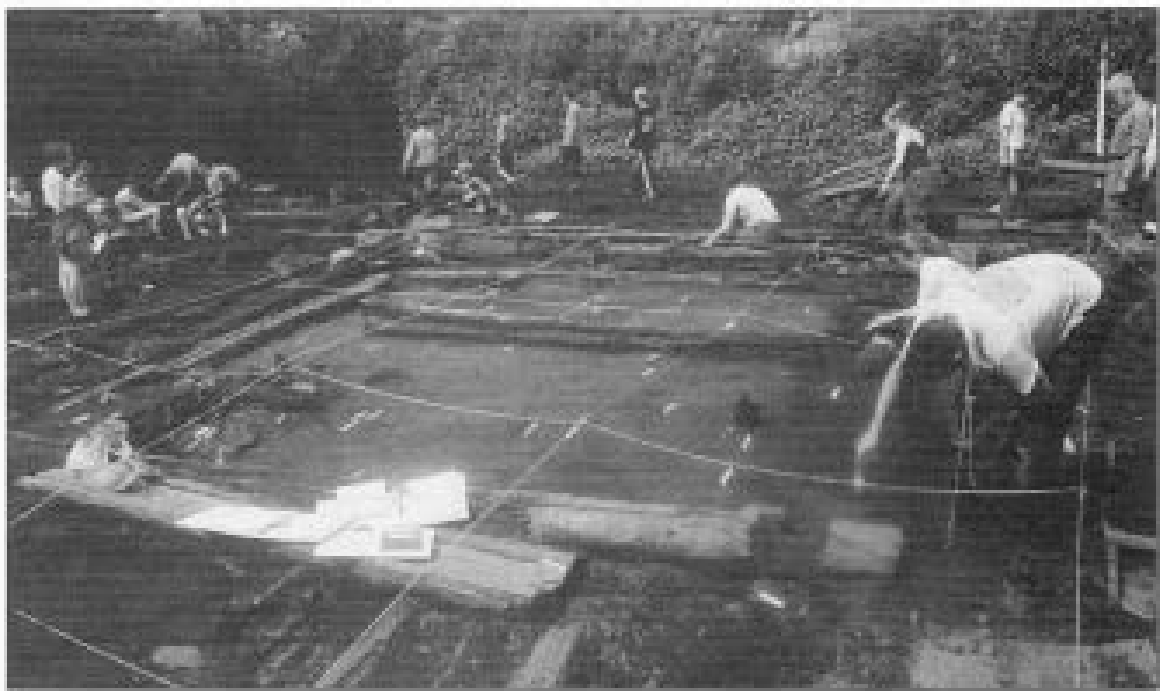

Figure 2 Single context area excavation at the Troitsky XII site, 1998; view from the southwest.

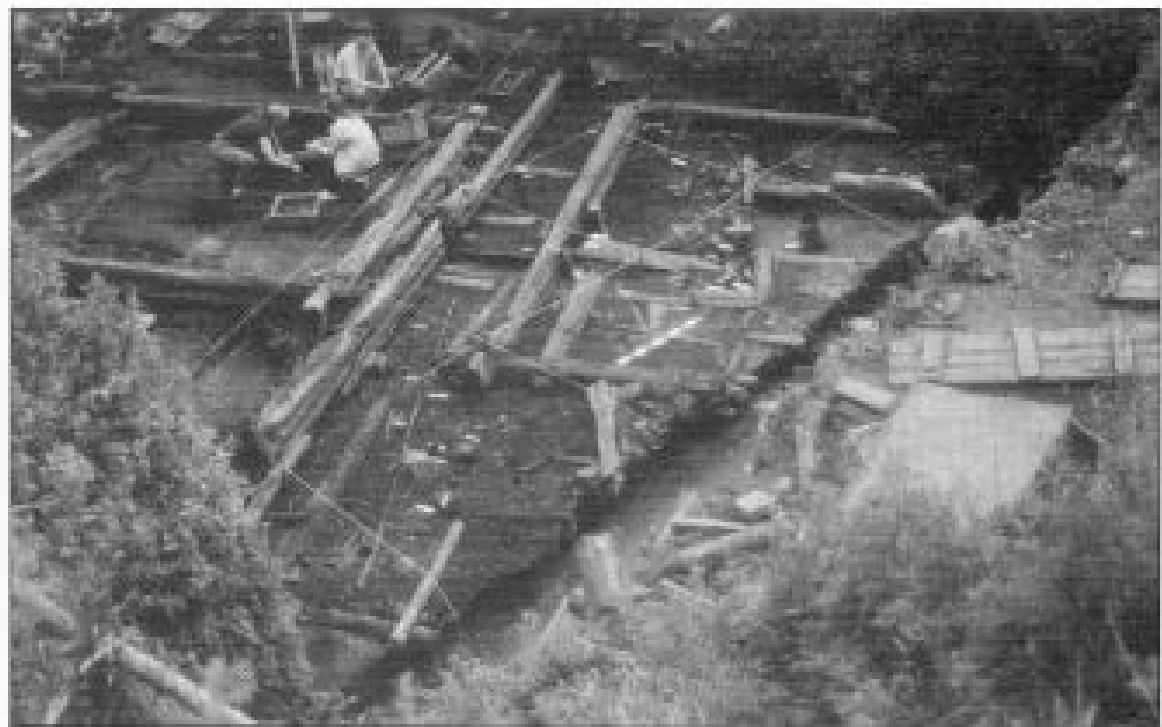

Figure 3 The mid-tent h-century building excavated by the UCL team in Troitsky XI; view from the northwest after removal of the plank floor (scale bar intervals $10 \mathrm{~cm}$ ).

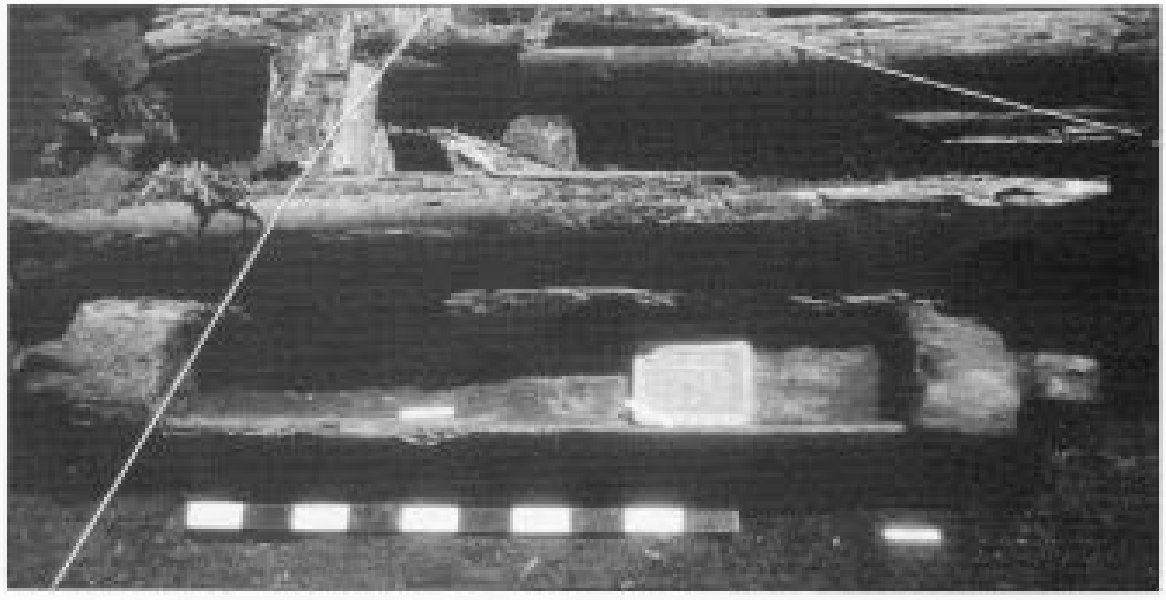

Figure 4 A mid-tenth-century watering trough found in an alley to the east of the excavated building in TroitskyXI (scale bar intervals $10 \mathrm{~cm}$ ). sky site south of the kremlin (Figs 1 and 2, and see Fig. 2 on p. 32 for the location of the site). In trench XI the Russian team had reached the earliest level of occupation, which dated to about AD 940, and additional research questions then became relevant. In an urban context, the earliest phase of occupation is of particular interest. It is important, for example, to establish whether the earliest periods of occupation were urban, proto-urban or rural in character, and to determine whether a town grew up "organically" or whether it was more deliberately planned. It is also important to establish whether a given settlement developed within pre-existing divisions of the landscape, such as fields, as it is often possible to identify ancient features fossilized in the modern layout of many towns and villages.

In Troitsky XI, the area examined by the UCL team lay at the west end of the trench (Fig. 3) and was defined to the east by a property boundary running northwest to southeast across the full $10 \mathrm{~m}$ width of the trench. The single context area (SCA) contained the eastern part of a two-room building with walls surviving to a height of three timbers. Both rooms were furnished with plank floors and divided from each other by a narrow screen formed of planks set between stakes, with additional support provided by uprights tenoned into the floor joists. The remains of an oven were found in the southerly of the two rooms, indicating that the building was a dwelling, but the south and west parts of the structurelay outside the area of excavation. A narrow alley containing a superbly preserved watering trough ran between the building and the property boundary at the eastern limit of the SCA (Fig. 4). To the north of the building was a timber road leading northwards out of the excavated area.

Once the floors had been recorded, the planks were individually sampled for wood identification and stored for inspection by a Russian colleague who is interested in the identification of re-used ship timbers. Below the timber floors lay a deposit containing woodworking waste, but also several worked wooden artefacts including a club with a decorated carved head, and a split willow stem probably used to bind a barrel. Although these finds were contained within the building, they appear to represent the rubbish generated by activities elsewhere on the site. The house was furnished with plank floors from the outset and the rubbish below them had probably been used to help level the planks. The structure itself had been erected in traditional Novgorod style, with logs laid one on top of the other with simple lap, or cup, joints at the corners (see Fig. 2 on p. 38). The base frame of the building lay over a thin layer of wood chips that continued to accumulate against the structure. Jon Hather's analysis of the woodwaste indicates that it derives from the construction phase; a contention borne 


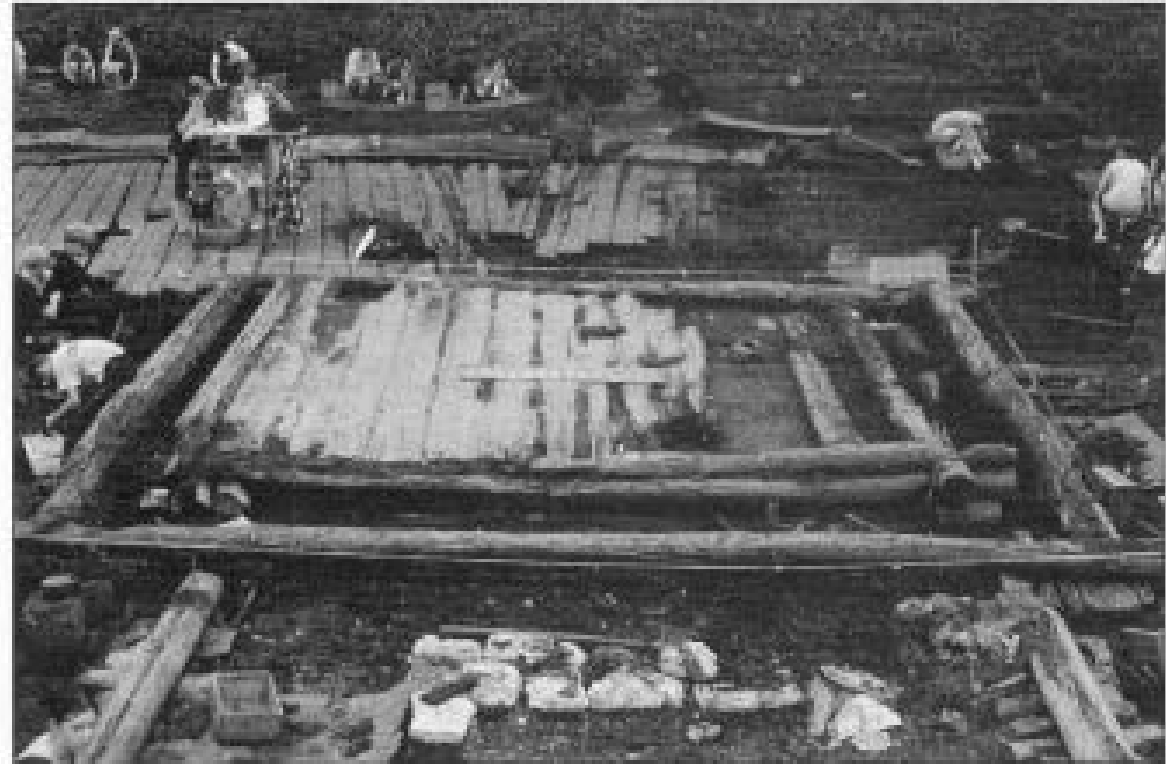

Figure 5 The later of the two mid-twelfth-century buildings excavated by the UCL team in Troitsky XII, showing its plank floor (scale bar $1.5 \mathrm{~m}$ ).

out by the presence of both primary (roughing-out) waste and secondary (finishing) waste in the layer. This woodworking deposit overlaid patches of still pungent dung which, in turn, overlaid grassland. Thus, we can infer that the house and associated structures excavated in Troitsky XI were built on the edge of an existing settlement, perhaps as an encroachment on a part of Novgorod's pastoral hinterland.

In Troitsky XII the Russian team had excavated about half a predicted sequence of $c .8 \mathrm{~m}$ in depth, and had reached a chronological horizon of the mid-twelfth century. The UCL team concentrated on an area measuring approximately $10 \mathrm{~m}^{2}$ in the middle of the extensive area of excavations (Fig. 5). Here, two successive structures were excavated that permitted an examination of house construction and demolition. The uppermost house measured $6.5 \mathrm{~m}^{2}$ externally and comprised an outer frame enclosing an inner frame of three sides that delineated an internal area of $4.5 \mathrm{~m}^{2}$. The east wall of the external frame formed the east wall of the inner structure. Doubleframe houses are common in medieval Novgorod and this feature is interpreted as an insulation cavity that would have been filled with a mixture of dung and soil as an added protection against the severe winter weather experienced in the region.

The structure was entered via a doorway in the east wall. Although no traces of the doorway itself survived, a massive tangentially split timber doorstep was found, set midway along the external face of the east wall. Internally, the building was furnished with a tightly jointed board floor laid over three north-south joists. There was no oven associated with this phase of occupation, and the location of the structure within a large high-status property suggests a specialized function. The plank floor was found to overlie an earthen floor with a contemporary oven in the southeast corner of the building. It seems reasonable, therefore, to suggest a change in function during the life of the building from a dwelling, perhaps of artisans, to a storage room, both within the context of a high-status urban estate.

After careful recording and sampling for wood identification, the building was unpicked from the dense deposits of woodworking waste derived from its construction. This revealed a layer of demolition waste derived from a structure that lay beneath. No attempt had been made to clear the demolition material from the site prior to erecting the later building, although the earlier structure had been robbed of its timber framing on the north and east sides. This earlier structure comprised a single frame

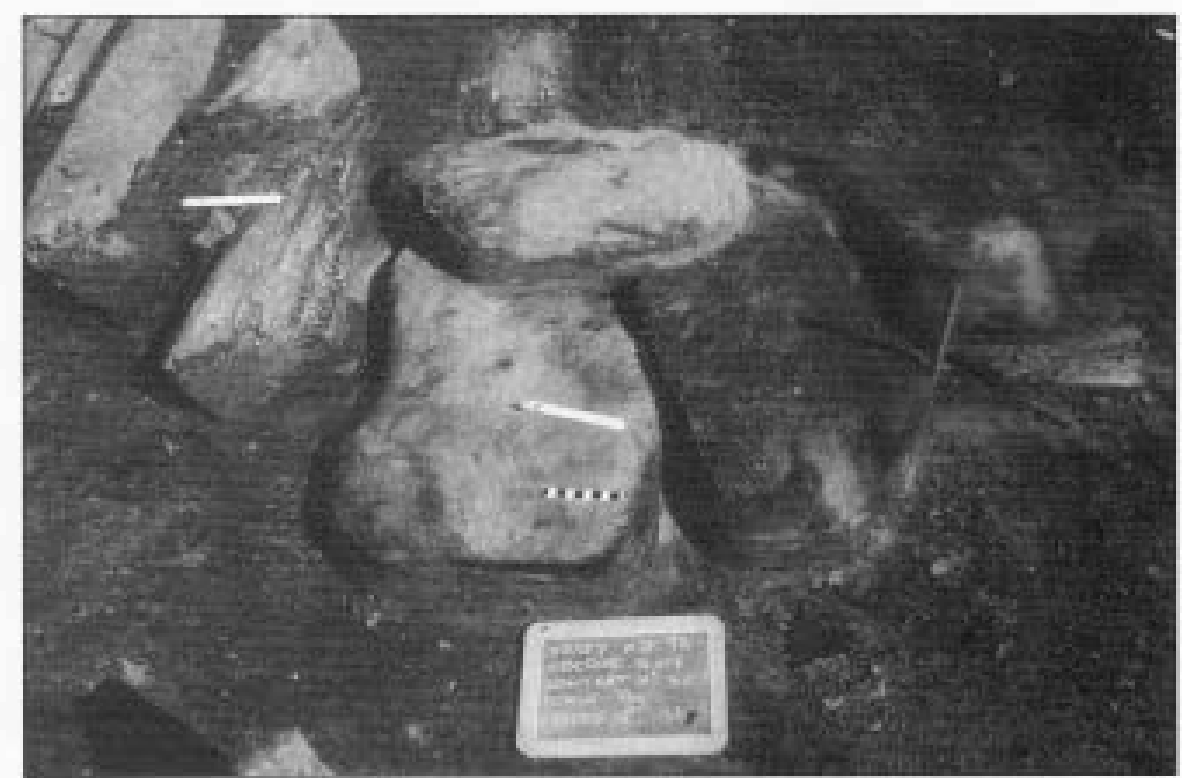

Figure 6 Four rotted sackscontaining sand found piled inside the east wallof the earlier building in Troitsky XII (scale bar intervals $1 \mathrm{~cm}$ ). and measured $4 \mathrm{~m}^{2}$, with only single timbers of the south and west walls surviving. Below the great doorstep of the later building was found a similar but smaller step, indicating continuity of access arrangements through the rebuilding programme.

Once the demolition layer had been recorded and removed, a clean floor of orange sand was exposed throughout the earlier building. Although cut, or "negative", features are considered a notable absence in Novgorod's urban archaeology, many of the upright posts associated with this building were found to be set into post holes. Furthermore, a feature of identical proportions to a grave was observed to have been cut through the sand floor in the western half of the building. This enigmatic feature contained nothing but the rapidly backfilled soil thrown up by the pit's diggers. A specialized function for this building was further revealed by our finding evidence of rotted sacks, some in piles, upon and within the orange sand floor (Fig. 6). The sacks themselves had rotted without trace, but their contents fine white sand - had been preserved in such a way as to leave no doubt about how it had been stored. The presence of these sacks throughout the orange sand suggests that a clean floor of sand was continually required. The purpose of the fine white sand is unknown, although it might have been used in industrial processes such as potting and metal casting.

The removal of the earlier building revealed the now-expected layer of woodworking waste that in turn sealed a layer of redeposited burnt material. This had been spread over the entire SCA. Russian colleagues had uncovered a burnt structure immediately to the south of the SCA and it seems that this event led to a clearing and preparation of the site for the erection of new buildings. 


\section{Results and reflections}

The 1998 excavations at Novgorod demonstrated the potential of single context recording. All three excavated structures were shown to have been built in situ and we infer from this that individual households would have been able to muster the range of skills necessary to build a house. Iron adzes and axes are common finds in the houses and yards of medieval Novgorod, and (as Jon Hather notes in the following article) these two implements were all that was required to prepare and finish structural timbers. Thus, the UCL team was able to demonstrate the value of the methods used by British archaeologists in urban contexts, and the collaboration also broadened the experience of those of us who were privileged to study at first hand a medieval townscape exposed on such a grand scale.

\section{Wood and woodworking in medieval Novgorod \\ Jon Hather}

W

aterlogged archaeological sites commonly preserve organic remains that normally decay in dry sites. The site of medieval Novgorod is deeply waterlogged, and it is also exceptional, in both the area and depth of its cultural deposits and the near-perfect condition of many of the organic remains recovered. Archaeological wood is excellently preserved at Novgorod and its abundance shows that the inhabitants used wood as a major resource-for building, for fuel, for the manufacture of domestic utensils, agricultural implements, fishing and textile manufacturing equipment,children's toys and many other purposes (Fig. 1).

The use of wood in Novgorod also reflects the town's location on the boundary zone (ecotone) between Northern Boreal woodland, dominated by pine, spruce and birch, and Central European Temperate woodland, containing hardwood species such as oak, elm, lime and ash. Both types of woodland were exploited in different ways by the town's inhabitants. A central

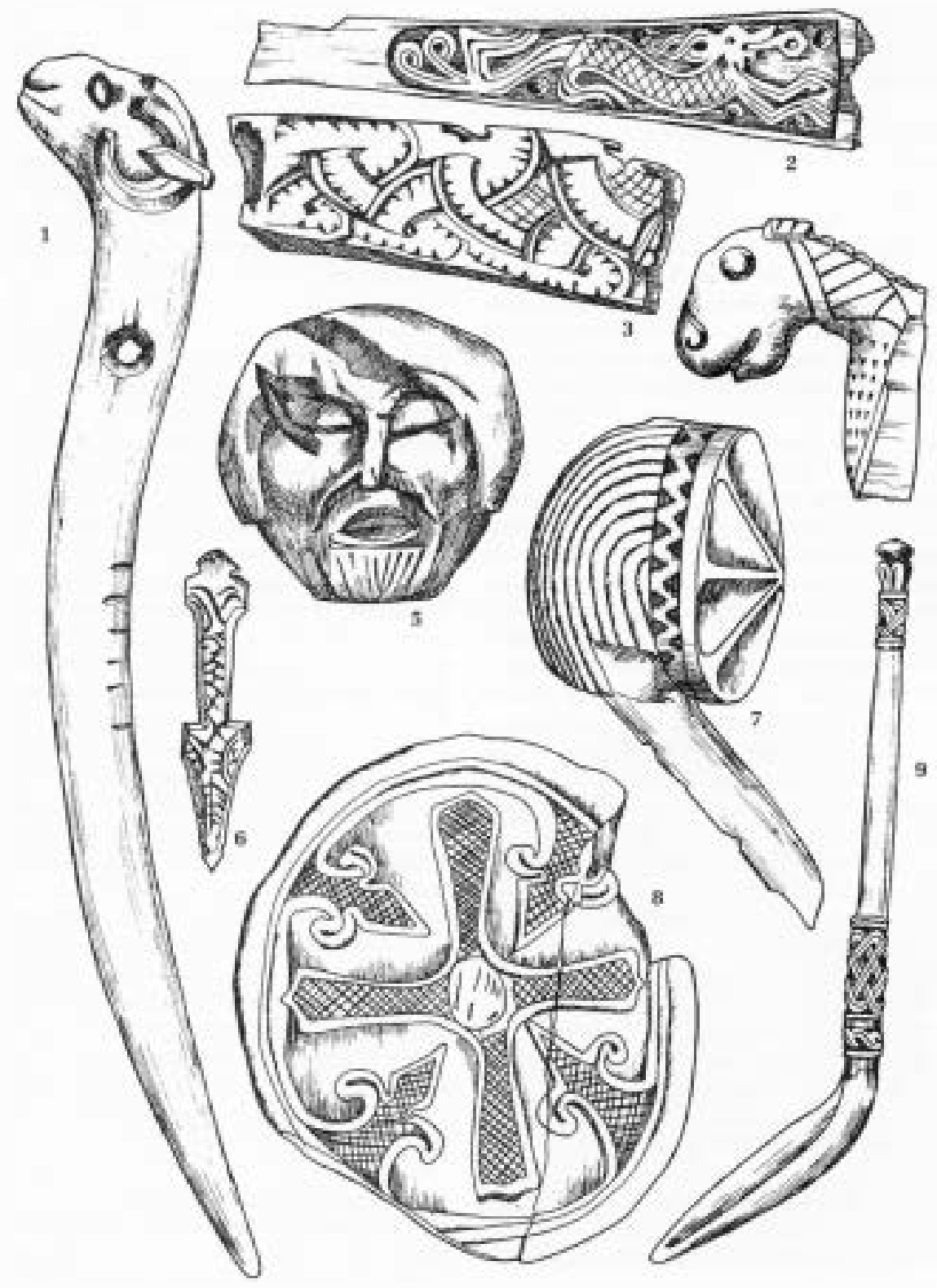

Figure 1 A selection of carved wooden objects from medieval Novgorod: (1) a rod with a ram's head terminal (use unknown); $(2,3)$ two sleigh-runner supports; the longer one, with a stylized dragon design, is from a child's sleigh; (4) the handle of a scoop or kovsh; (5) a sculpted male head;(6) a miniature dagger; (7) a terminal (use unknown); (8) a vessel lid; (9) a spoon (from fig. V.2 in Brisbane (ed.); see n. 2 on p. 33). 
aim of the recent investigations at Novgorod has been to interpret the range of ways in which wood was used in a medieval urban society. We are also studying changes in the woodlands that resulted from human exploitation and the effects they then had on the use of wood by craftsmen.

\section{Excavation and analysis}

Novgorod archaeologists have been meticulous in recording and conserving wooden artefacts ever since excavations began. Publications by Boris Kolchin and his colleagues between the late 1950s and the mid1970 s led Europe in the analysis of wood from waterlogged sites, introducing concepts that brought together scientific and humanistic disciplines in the investigation of Novgorod's archaeology. However, the relative inaccessibility of Russian archaeological literature to western European archaeologists, and the difficulties in funding Russian archaeology in recent years, have meant that much of this pioneering work has fallen into obscurity. Nevertheless, continuing excavations in Novgorod have provided opportunities for Kolchin's pioneering work to be carried forward.

The primary sources of evidence used in these investigations are structural and artefactual wood; woodworking waste derived from the manufacture of buildings as well as domestic and industrial articles; and charcoal from the burning of wood as fuel. During the 1998 season, wood analysis centred upon the excavation of a midtwelfth century house of "log-cabin" type within the Troitsky XII trench just south of the kremlin. The excavation was carried out by Andrew Reynolds (see his article on pp. 34-37) with a team of students from the UCL Institute of Archaeology and the Department of Conservation Sciences of Bournemouth University. Species identifications of samples of structural and artefactual wood and woodworking waste were made in Novgorod, and charcoal was sampled for later analysis at the Institute in London.

A part from the very earliest buildings in Novgorod, which make use of oak for the foundation timbers, pine and spruce seem to have been used more or less exclusively for the main structural elements of the buildings. Other species were often used for minor structural elements and for decoratively carved embellishments. In the twelfth-century house, 30-40-year-old pine and spruce were used for the wall timbers, although larger pine trees seem to have been used where more substantial timbers were needed. Woodworking waste, which included many axe chips of pine and spruce from the primary conversion of timber, indicates that the house was built in situ. Waste from both axe and adze working of hardwoods - birch, oak, ash, lime and alder - was also present; and preliminary analysis of the charcoal sample indicates a predominance of pine and spruce.

\section{Builders and craftsmen}

The conclusion that the excavated twelfthcentury house was built in situ raises the question of who the carpenters were who constructed Novgorod's buildings, and to what extent different levels of specialized woodworking skills can be recognized. It is likely that a building such as the excavated house was constructed by only two or three people. It would certainly require no more than two people to move timbers from a stockpile into position and to maintain order in the progressive build up of the walls; if more than two or three people are involved, the ordered sequence of building may well falter. The level of craftsmanship needed is relatively low, a view supported by the fact that the only two tools used, the axe and the adze (Fig. 2), would have been available to most people in the town. This suggests that the builders are likely to have been the people who would have occupied the completed house.

The woodworking waste of hardwood species found associated with the house also suggests that the people using it, or those using buildings close by, knew how to work these timbers - to make domestic utensils, agricultural implements, and so on, and perhaps to carve decorations for the newly constructed house. The presence of such waste implies a level of unspecialized woodworking being practised by people for themselves, using only axe and adze, and possibly a knife. It is possible that tools such as the drawknife and chisel were also employed, although waste resulting from the use of these tools was not found.

The conclusion to be drawn is that there was a level of woodworking skill familiar to everyone and widely practised, using tools to which most people would have access, to make objects for personal use. This contrasts with specialized woodworking that would have been carried out professionally by woodworkers who depended on their trade for an income. Such craftsmen would have required specific tools beyond those commonly available, for example the turner's and spoonmaker's hook tools and the cooper's drawknife. The professional woodworker's specialized skills - cooperage, turning, musical instrument manufacture, and so on - would have been gradually acquired through a lifetime's practice, probably initially learned from an elder and not available to people who only occasionally needed the specialized products of such woodworking.

\section{Woodland management}

The evidence at Novgorod for woodworking craft specialization has yet to be analyzed. The aim of this analysis is to try to determine from four sources of evidence woodland resources, woodworking waste, tools and artefacts - what levels of craft specialization were practised. Pine and spruce were plentiful in the Boreal woodland, but the hardwoods of the Temperate woodland

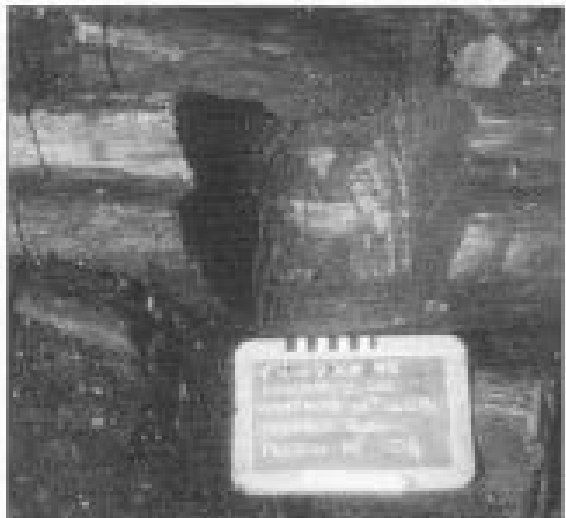

Figure 2 A traditional Novgorod cup joint found at the northeast corner of a building made of pine and spruce logs in trench XII at the Troitsky site; the joint shows well preserved axe marks (scale bar intervals $1 \mathrm{~cm}$ ).

were at their very northern limit and grew slowly. Once felled, large hardwood trees would be replaced only slowly by natural regeneration. If woodlands were managed, either by coppicing or by restricting access to them, it is likely that this would have been undertaken to provide a resource for specialized woodworking crafts. Analysis of craft products, together with the evidencefor unspecialized wood working, may provide insights into both levels of craftsmanship and the access craftsmen had to woodland resources. This in turn will improve our understanding of what impact a medieval town such as Novgorod may have had on its environment. 